\title{
Chinese Hegemony: What Kind of Global Power?
}

\author{
Çağla Kılıç \\ Bilkent University
}

\section{Review article of two books:}

1. Feng Zhang, Chinese Hegemony: Grand Strategy and International Institutions in East Asian History (Stanford: Stanford University Press, 2015, 280pp., USD 61.01, hardcover)

2. Sebastian Harnisch, Sebastian Bersick, and Jörn-Carsten Gottwald, eds. China's International Role: Challenging or Supporting International Order? (New York: Routledge, 2016, 276 pp., USD 145, hardcover)

Chinese foreign policy behavior has become a central concern for scholars and countries as China has become increasingly pivotal in international politics. Questions being explored include: Will China be the next hegemon? If so, what kind of hegemon will China become? Would it be a different global power as it claims to be 'peaceful' and 'just,' or would we have the same international order with a different principal actor? Is it possible for China to have a normatively desirable relational strategy in the present? And more importantly, what is the role of China's ancient philosophical past, such as tianxia (meaning 'under-earth') and the tribute system, in understanding these arguments? These concerns highlight the need for more awareness of the political mindset that underlies China's foreign policy. Examining this mindset is a response to the proliferating global interest in China and enhances the awareness of Chinese leaders' governing philosophy(ies). This review will focus on two recent books, both of which aim to provide answers to above questions.

China's International Roles: Challenging or Supporting International Order? by Sebastian Harnisch, Sebastian Bersick and Jörn-Carsten Gottwald, is an edited volume providing a wide range of perspectives on role theory and newly emerging hegemons. Role theory is interdisciplinary, and provides a descriptive conceptual language using different levels of analysis. ${ }^{1}$ According to Yudan Chen, role theory is very suitable to study China since it melds well with Chinese thought. ${ }^{2}$ For example, the Chinese historical mentality regarding state governance gives different roles to the state, such as 'teacher' (as in Confucian understanding, where it is believed that the state's main duty is to educate society and help people gain moral values) or the 'central state' (as in the tianxia conception, associated with a political system where the earth is divinely appointed to the Chinese emperor, who rules the

\footnotetext{
Çağla K1lıç, MA Student, International Relations Department, Bilkent University. Email: cagla.kilic@bilkent.edu.tr.

1 Yudan Chen, "Philosophy, Identity, and Role Theory with 'Chinese Characteristics'," in China's International Roles: Challenging or Supporting International Order? ed. Sebastian Harnisch, Sebastian Bersick, and Jörn-Carsten Gottwald (New York: Routledge, 2016), 77.

2 Chen, "Philosophy, Identity, and Role Theory," 78.
} 
world in harmony and provides stability). The Chinese perception of roles is also rich enough to provide new insight and comprehension to role theory itself. China's International Roles not only provides insight to the formation of Chinese roles by analyzing role conceptions, but also explains the changes in China's roles over time, and is well-grounded in the historical evidence. Therefore, the book goes beyond a 'snapshot' role-theory analysis of Chinese foreign policy at a specific time, as it is an attempt to provide an overall and longitudinal picture of the country's foreign policy history.

China's International Roles consists of three sections. The first establishes the theoretical basis for the next sections and mostly focuses on the historical and philosophical backgrounds that inform China's contemporary roles. The second section mainly concentrates on the manifestation of China's roles in the global context, such as its relationship with the United States and its engagement in international economic and financial institutions. The third section focuses on the regional context and deals with China's relationships with other countries or entities such as the European Union, Africa or socialist states from a role theory framework. The concluding chapter (written by the editors) points to China's hard choices between conflicting domestic and external expectations regarding its international roles, and presents three arguments: First, that China's international roles are a product of domestic debates on the legitimacy of one-party rule. Second, that China's domestic role expectations are variable and have changed over time, from a revolutionary great power to peaceful codependence. Finally, as for almost all states, China's roles and the domestic order supporting them are partly a product of international altercasting, learning and socialization.

The first section of the book provides a theoretical framework that enables the reader to analyze China's contemporary roles. The section is composed of five chapters, with the last one particularly interesting: Yudan Chen shows how early theoretical or philosophical Chinese thought provides insight into China's current roles. He argues that China's behavior is not rooted only in power and survival, but is also determined by the roles China established for itself and the roles that have been established through its interaction with others. Chen proposes that analyzing China with the existing assumptions of role theory is not sufficient because of the embeddedness of its unique history and deep culture. Accordingly, Chen provides three essential concepts of "Chinese Characteristics"3 to interpret and comprehend Chinese behaviour roles: the Weiqi metaphor, the fantasy novel metaphor and the flower and butterfly metaphor. Weiqi is the Chinese word for the famous game of 'Go.' As in the game, the metaphor proposes rapid change and a flowing nature instead of stable and predefined roles. In Weiqi, one must speculate on a certain token's role not by what attributes it has but by its movement. The role is determined by the token's momentum, which can be grasped through experience and comprehension, or as the Chinese call it, shi. ${ }^{4}$ Therefore, the meaning of each role depends on where, how and when it appears and in which situation. ${ }^{5}$ With its distinct pieces playing different roles, chess may represent a Western understanding of the international order. Similarly, Weiqi illustrates the philosophical world view and strategic thinking of the Chinese people.

The second metaphor, the fantasy novel, refers to Chinese philosophers' belief in the harmony of intra- and inter-roles, or the "co-implication" of polarities and the mutually 
inclusive co-existence of counter-roles. ${ }^{7}$ Apparently, there is little role conflict between Chinese roles, just as there are no sharp distinctions between a student and teacher in Confucian understanding. Teachers can continue to learn by maintaining their student role and students can have a certain amount of knowledge that gives them the status of teacher. Having two 'opposite' roles does not necessarily lead to a role conflict; instead, it can lead to role harmony, like Ying and Yang. This Ying-Yang duality can be seen in Sino-US relations: On the one hand, China has an active and assertive foreign policy in the South China Sea, and on the other, it espoused a 'peaceful development' rhetoric during Hu Jintao's time in office. Thus the two roles may exist without an existential conflict.

The final metaphor, the flower and the butterfly, implies that both the 'objectified' self and 'subjectified' other are significant when creating or altering a role. For example, when a Western poet sees a flower, he plucks it to pursue the knowledge about 'what is.' When an Eastern poet notices the flower, he leaves it be and contemplates it in its sono-mama (natural) state, ignoring the distinction between the self (subject) and the object. This blurring between object and subject is best exemplified in the famous poem, Butterfly Dream, by the Taoist poet Zhuang Zhou. ${ }^{8}$ The narrator dreamt of being a butterfly and when he woke up, he was not sure whether he was a butterfly dreaming of being a human or a human dreaming of being a butterfly. This blurry situation between the self and other reflects the internalization of other and the distinct understanding of Chinese roles.

The above three metaphors imply that China's roles are fluid rather than stable, adapting through time and space. They are also instrumental in comparing the formation of China's grand strategy to that of the US' ${ }^{9}$ The former appears to be more ambiguous than the latter, despite similar interests such as security, political stability and prosperity. ${ }^{10}$ The two strategies mainly differ in the way they view the world. While the American grand strategy wishes to promote a specific set of norms or rules (because other rules or existing norms are perceived as potential threats and must be changed), the Chinese grand strategy does not promote a substantive norm, and China has the image of a role conformer. As a result, the image of the US as a 'liberal nation' translates into interventionist policies. The US measures friends and foes against its own standards and values, which were created by its own practices, including market openness and competitive elections. In contrast, China encompasses all other players and promotes recognizing a greater self. It does not care whether others have different normative values (even in border disputes with India, Vietnam or North Korea); it is more important to achieve a common understanding.

The self-ascribed roles of China and the US further differentiate the two countries' grand strategies. China embodies a sociological role conception with a relationship-based style; its self-ascribed role is as a 'responsible major power'"1 that wants to build a harmonious world in which there are no universal values or norms. America's foreign policy, on the other hand, adopts a psychological identity-based role with an ego-oriented style. Hence, having the power to impose sanctions in order to spread its 'universal' values is central to the American grand strategy, where Chinese grand strategy is mainly about achieving harmony through

\footnotetext{
Chen, "Philosophy, Identity, and Role Theory," 81

8 James Legge, trans., The Texts of Taoism: The Tao Te Ching of Lao Tzu; The Writings of Chuang Tzu, Part 1, repr. ed. (New York: Dover Publications, 1962), quoted in Chen, "Philosophy, Identity, and Role Theory," 83.

9 Chih Yu Shih and Chiung-Chiu Huang, "The Identity and International Role of China: Regional Grand Strategy," in China's International Roles, 58

10 Shih and Huang, "The Identity and International Role of China," 60.

11 Shih and Huang, "The Identity and International Role of China," 60.
} 
multi-lateral cooperation, Chinese networking (guanxi) and win-win cooperation. China's guidelines for operation are based on multilateral benefits, and, as a hegemonic power, China would ensure this system works to achieve a harmonious, stable and peaceful world.

The second section of China's International Roles is composed of four articles, which mostly highlight the dynamics at play between China's new status as a role-maker and its previous status as a role-taker. Two articles stand out in this section. The first is Cameron Thies' article on China's changing relationship with the US, especially the former's response to altercasting attempts by the latter. Thies defines altercasting as endowing "a particular identity or role type"12 onto someone (or some country) to persuade them to behave in a desired manner. During the US' open-door-policy period, it projected a series of roles onto China, including 'great power,' 'troubled modernizer,' 'failed modernizer' and 'protectee.' ${ }^{13}$ Currently, however, China is less likely to adopt a role identity given by the US. For example, China rejected the role of 'failed modernizer,' which changed the course of SinoUS relations. China is also starting to counter-cast roles to the US, which is a challenge to US hegemony and the existing international system. ${ }^{14}$ In the final article of this second section, Mikko Huotari argues that China's inclination to exercise leadership began ${ }^{15}$ with the global financial crises in Asia, when China wanted to be known as a 'great power' for the first time since the Deng Xiaoping era. The crises reminded China of the importance of an informal 'neighborhood policy,' and accordingly, China's new security concept included sustained development and multifaceted economic security. ${ }^{16}$ The description of Sino-US relations as "great power relations" by Xi Jinping can also be evidence of this change. China's push for greater regional leadership gained momentum especially after $2001 .{ }^{17}$

In the third section, Nele Noesselt's article presents a rather distinct take on role theory. He argues that national role conceptions are used to justify countries' political decisions. He emphasizes that while China praises the regimes of Vietnam, North Korea and Cuba as socialist brothers, the deficits and failures of socialist states such as the USSR are utilized to legitimize China's economic reforms. In official Chinese discourse, it is claimed that open market regulations and engaging in international trade are not indications of Chinese capitalism. Rather, they are a strategic move, compulsory for the survival of socialism in the twenty-first century. Thus, China's 'socialist role' should mostly be viewed as a system of justification rather than as a direct guide to China's foreign policy behavior in the international system.

Noesselt claims that China's self-identification as a daguo (great power) and as part of the developing countries of the Global South currently dominate Chinese role conceptions. Equally important, however, is China's promotion of itself not only as a nation-state (guojia) but also as a tianxia (modern empire), which constructs the country's identity in contrast to expansionist/colonial empires. Thus, tianxia has a huge impact on the formation of China's current roles as a peaceful rising power that proposes a harmonious, stable, Confucian world under a benevolent hegemon.

12 Cameron Thies, "The US and China: Altercast Roles and Changing Power in the 20th Century," in China's International Roles, 98.

13 Thies, "The US and China," 102.

14 Thies, "The US and China," 100.

Mikko Huotari, "A New Role in East Asian Financial Order," in China's International Roles, 157.

16 Huotari, "A New Role in East Asian Financial Order," 147.

17 Huotari, "A New Role in East Asian Financial Order," 150. 
China's International Roles not only captures the evolution of Chinese roles through time and space but also provides a philosophical and historical perspective to understand the emergence of these roles. It implies that China may become a different hegemon than the previous or existing hegemons in terms of its unique roles, but definitely not an unusual one in terms of its aggressive practices. That is, despite China's harmonious goals, it may still need to engage in warfare.

In the book Chinese Hegemony: Grand Strategy and International Institutions in East Asian History, Feng Zhang provides a different (and more positive) answer to the initial questions. Zhang acknowledges the importance of the following questions: What will China do with its new power? and What will China want? ${ }^{18}$ He explains that despite the Chinese government's persistent denial of any hegemonic ambition throughout the reform era, some scholars in the country predict that China will evolve into a "humane authority" 19 hegemon. In contrast, some foreign scholars think that China will become a different but not unusual global power in terms of its aggressive practices or it will be the same type of hegemon as the US. ${ }^{20}$ Acknowledging that China is economically and politically rising, Zhang cautions that the historical analogies do not offer great insight, and the current trends are not sufficient or reliable enough to answer the following question: Will China become a hegemon? $\mathrm{He}$ suggests that China will be a different hegemon in terms of its aggressive practices, values and attitudes than previous or existing hegemons (in this case the US), and that a strong China can be as peaceful and benign as its imperial predecessor supposedly was. This book also suggests revisions to Western-dominated IR theories by offering certain cases from East Asia.

Chinese Hegemony consists of seven chapters. The first is an introduction emphasizing Chinese material primacy in East Asia during the Ming Dynasty. In the second chapter, Zhang establishes a three-part conception of the relational international structure in the East Asian context and explores the implications of this framework for China's grand strategies in general. The third, fourth and fifth chapters apply the relational theory to three sets of bilateral relations: Sino-Korean relations, Sino-Japanese relations and Sino-Mongol relations. Chapter Six explores the implications of Zhang's relational theory with respect to the "fundamental institutions in [the] East Asian order," 21 and argues that a distinct international society existed during the early Ming Empire. Finally, in Chapter Seven, Zhang focuses on the value of relationalism in examining and understanding IR in East Asia, and proposes ethical relationalism as a critical and normative IR theory that partially informs Chinese foreign policy.

Zhang's analysis introduces the expressive side of the Chinese strategy by examining one of the major dimensions of East Asian IR - relationality, and argues that the theoretical framework of relationalism is a distinct feature of Chinese diplomacy. ${ }^{22}$ Rather than an actor-based ontology, he proposes a relational ontology, ${ }^{23}$ which takes mutual relations as the primary unit of analysis. An actor is regarded as a "process of becoming" rather than

18 Feng Zhang, Chinese Hegemony: Grand Strategy and International Institutions in East Asian History (Stanford: Stanford University Press, 2015), 3.

19 Zhang, Chinese Hegemony, 1

20 Zhang, Chinese Hegemony, 2.

Zhang, Chinese Hegemony, 154

22 Zhang, Chinese Hegemony, 22

23 Zhang, Chinese Hegemony, 23 
as a "being" ${ }^{24}$ embedded in interconnected events with an interdependent co-existence. This theory thus provides a non-Western perspective in understanding Chinese and Asian networking and patterned relationships.

Zhang indicates that there are three main relational structural components of the East Asian system: ordering principles, differentiation of roles and distribution of ties focusing on actor-degree centrality. The ordering principle of the international system can be expressive or instrumental. Instrumental logic is pragmatic, and aims to maximize one's interests, whereas expressive logic embodies Confucianism and aims to create ethically endowed relations merely for the sake of doing so. The differentiation of roles, also inspired by Confucianism, implies that different roles require different ethical principles of action, and these determine the quality of relationships. Roles are differentiated along two hierarchical axes: a sovereignsubordinate and a father-son relationship. The emperor of China is the father or the sovereign of the world and the rest of the people are his subordinates or sons. Finally, the distribution of ties focusing on actor-degree centrality, which is derived from social network analysis, assumes that the central actors in a social network are the most. Hence, their social power depends on the degree of their centrality, which is indicative of their prominence in the system.

Zhang argues that it is possible to reestablish the Confucian value of humaneness and practice it in IR. China's common historical model for such interactions is the tribute system, a network of trade and mutually beneficial economic relations between China and its independent tributaries. Zhang makes a two-fold argument around this model. On the one hand, he accepts that the tribute system can be usefully conceptualized as a distinct international society, but on the other, conceptualizing the East Asian order as such is inadequate to fully comprehend the region's relational dynamics. The tribute system contained inherent limits, and was only one of several fundamental institutions that helped maintain regional order. Moreover, tributary diplomacy was not always the dominant or most significant in the system.

Hegemony entails a high degree of hierarchical authority, which not only requires material capability but also a sense of social purpose, the capacity to control significant outcomes in the international system and a certain degree of consent to, as well as social recognition and acceptance of, the hegemon by other states in the system. According to Zhang, in the early Ming Dynasty the Chinese possessed a reasonable but incomplete regional hegemony given the politics. Zhang believes that hegemony is always incomplete - including that of the US. Setting the rules of the game does not necessarily guarantee the obedience of the rivals or even the supporters. Recognition makes a hegemon's international rules and institutions legitimate, thus central to an understanding of relational hierarchy, that is, a relationship of legitimate dominance. Questioning the true meaning of the word 'hegemon' in the first place, Zhang proposes an interesting way to understand China's rise. He presents China's historical domination in East Asia by providing a deep understanding of its historical past, and allows the reader to contemplate its new (possibly hegemonic) role by providing a theoretical, historical and philosophical background. He claims that a hegemonic relationship does not necessarily need to be malignant, as the concept of domination implies.

Chinese Hegemony contributes to the debate on the title subject by providing a historical perspective into IR's strategic and institutional dynamics and the hegemonic experience in 
East Asia. By emphasizing the importance of historical analogy and theoretical deduction, Zhang suggests that we should take lessons from the past if we want to predict the future and understand its contemporary policy implications. This approach, however, does not mean that historical instructions can be utilized in the strategic development of a re-emerging East Asian order; doing so may risk historicism.

The two studies agree on one major point: To understand China's current rise in the region we need to understand its historical role in East Asia. From this point of view, both books provide deep insight into China's history and the impact of the country's philosophical past (especially that of Confucianism) on its contemporary policies. Both present specific and strong case studies to strengthen their analyses and contribute to the IR literature in unique ways. Equally important, they warn the reader against simplistic and consolidated conceptions of China.

\section{Bibliography}

Zhang, Feng. Chinese Hegemony: Grand Strategy and International Institutions in East Asian History. Stanford: Stanford University Press, 2015.

Harnisch, Sebastian, Sebastian Bersick, and Jörn-Carsten Gottwald, eds. China’s International Roles: Challenging or Supporting International Order? New York: Routledge, 2016. 